\title{
Isolation, Identification \& Characterization of Gram Negative Bacteria from Popular Street Food (Chotpoti) at Savar Area, Dhaka, Bangladesh
}

\author{
A. H. Happy ${ }^{*}$, M. G. Alam¹, S. Mahmud2, M. A. S. Imran², M. H. Rony', M. A. A. Azim³, M. M. Islam,

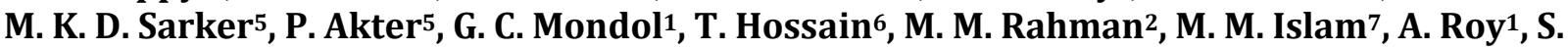 \\ Das', M. R. Ahmed1, M. E. Uddin'
}

${ }^{1}$ Department of Microbiology, Gono Bishwabidyalay, Dhaka, Bangladesh

${ }^{2}$ Department of Biotechnology and Genetic Engineering, Islamic University, Kushtia, Bangladesh

${ }^{3}$ Department of Microbiology, Jahangirnagar University, Dhaka, Bangladesh

${ }^{4}$ Department of Microbiology, Jagannath University, Dhaka, Bangladesh

${ }^{5}$ Department of Microbiology, Stamford University Bangladesh, Dhaka, Bangladesh

${ }^{6}$ Department of Physiotherapy, Gono Bishwabidalay, Dhaka, Bangladesh

${ }^{7}$ Department of Bioscience and Biotechnology, The University of Suwon, Hwaseong, Republic of Korea

${ }^{8}$ Department of Biochemistry and Molecular Biology, Gono Bishwabidyalay, Dhaka, Bangladesh

Email: *afrozahappy@ymail.com

How to cite this paper: Happy, A.H., Alam, M.G., Mahmud, S., Imran, M.A.S., Rony, M.H., Azim, M.A.A., Islam, M.M., Sarker, M.K.D., Akter, P., Mondol, G.C., Hossain, T., Rahman, M.M., Islam, M.M., Roy, A., Das, S., Ahmed, M.R. and Uddin, M.E. (2018) Isolation, Identification \& Characterization of Gram Negative Bacteria from Popular Street Food (Chotpoti) at Savar Area, Dhaka, Bangladesh. Open Access Library Journal, 5: e4986.

https://doi.org/10.4236/oalib.1104986

Received: October 15, 2018

Accepted: November 20, 2018

Published: November 23, 2018

Copyright $\odot 2018$ by authors and Open Access Library Inc.

This work is licensed under the Creative Commons Attribution International License (CC BY 4.0).

http://creativecommons.org/licenses/by/4.0/

\begin{abstract}
Chotpoti is a popular street food in the major areas of Bangladesh. Street foods play an important role in people's daily food options as well as their regular nutritional requirements are dependent on these foods, as their ever-growing busy schedule takes away the opportunity to eat of homemade food. Due to the expedient availability, these street foods are one of the primary food options for city peoples. The present study was undertaken to investigate the microbiological quality of Chotpoti sold by different street vendor at Savar area, Dhaka, Bangladesh. Microbial quality was assessed by total viable count (TVC), total coliform count (TCC); samples were inoculated into various selective media such as Nutrient agar, Eosin Methylene Blue (EMB) agar, Salmonella Shigella (SS) agar, Thiosulfate Citrate Bile Salts Sucrose (TCBS) agar and Mac Conkey's agar. Gram negative bacteria were isolated and identified from the samples. The TVC in Chotpoti sample was ranged from $6 \times 10^{5} \mathrm{CFU} / \mathrm{g}$ to TNTC and TCC was ranged from $6 \times 10^{5}$ $\mathrm{CFU} / \mathrm{g}$ to $3 \times 10^{6} \mathrm{CFU} / \mathrm{g}$. Antibiotic sensitivity test showed that the isolates were sensitive to antibiotics such as antibiotic against Streptomycin, Chloramphenicol. Data of this study indicated that Chotpoti sold at street around
\end{abstract}


Savar region harbor multidrug resistant food borne bacteria which might cause public health hazards.

\section{Subject Areas}

Genetics, Microbiology

\section{Keywords}

Isolation, Street Foods, Identification, Antibiotic Sensitivity and Public Health Hazards

\section{Introduction}

Street food is ready-to-eat food in a street or other public place, such as a market or fair, by a hawker or vender, often from a portable food booth [1] food cart or food truck. The street foods are the well appreciated by consumers, due to its taste, low cost, nutritional value and availability for immediate consumption [2]. Contamination might also occur due to poor food handling practices of the vendors as most vendors lack awareness and knowledge of handling of food safety and have not been formally trained in food safety [3]. Small fried fish, a street food in ancient Greece [4] although Theophrastus held the custom of street food in low regard.

Over the years, many food-borne diseases have been reported due to contaminated non-homemade food consumption. Street food was widely utilized by poor urban residents of ancient Rome whose tenement homes did not have ovens or hearths, with chickpea soup being one of the common meals along with bread and grain paste [5]. In ancient China, where street foods generally catered to the poor, wealthy residents would send servants to buy street foods and bring meals back for their masters to eat in their homes [6]. As of 1707, after previous restriction that had limited their operating hours, street food vendors had been banned in New York City [1]. Most of the members of Enterobacteriaceae cause gastrointestinal problems in human body [7]. In the 1800s street food vendors in Transylvania sold ginger bread-nuts, cream mixed with corn and bacon and other meat fried on tops of ceramic vessels with hot coals inside.

Bangladesh is populated with many vendors of street foods of different kinds. Like all developing countries, street food preparation and selling in Bangladesh provides a regular source of income for millions of men and women with limited education or skills. Almost all of the bacteria are pathogenic to human at various degrees and infections caused by some bacteria are even hard to treat with increase the rate of antibiotic resistance in the community [8]. The prevalence and growth of all pathogens on the raw foods especially vegetables, salads, fruits and sprouts, are used as ingredients of chutneys [9] [10]. Especially the rickshaw puller, laborers eat street foods just to satisfy their hunger. Rickshaw puller, laborers, informal sectors (43\%), white-coller workers (19\%) student's children 
(12\%), others (26\%) [1]. There are 128 varieties of street foods found in Bangladesh. Among them Chotpoti, Belpuri, Samucha, Jhalmuri, Daalpuri, Lassi, Pakura, Halim are most popular [11].

Presence of antibiotic resistant bacteria in street-foods has become a global health concern. Street food vending has become an important public health issue and a great concern to everybody. Microbial food borne illness is the major health problem associated with street foods [12]. Food handlers can also become carriers of the pathogenic food microorganisms such as Salmonella spp [13]. Some of the phenolic compounds present in various foods have antimicrobial activity against gram negative bacteria [14]. Street food importance has consequences such as its association to epidemic and disease outbreak in case of the microbiological quality failure [15]. The objectives of this study were microbiological analysis of Chotpoti, to find out the presence of enteric bacteria and to describe the characteristics and practices with regard to street food among the people.

\section{Materials and Methods}

\subsection{Study and Sample Collection Site}

The study was conducted during the period from June to December 2014, in the Department of Microbiology, Gono Bishwabidyalay, Savar, Dhaka. Chotpoti samples were collected from different street vendors at Ghorapir Mazar stand

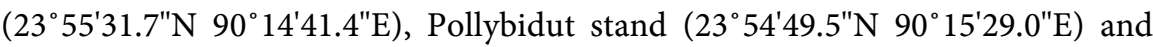
Nabinagar bus stand $\left(23^{\circ} 54^{\prime} 49.5^{\prime \prime} \mathrm{N} 90^{\circ} 15^{\prime} 29.0^{\prime \prime} \mathrm{E}\right)$. All the samples of this study were collected aseptically using sterile instruments and transferred carefully to appropriate containers. The samples were carefully handled and kept in box. Due aseptic care was taken during transportation and the samples were kept in sterile container until they are prepared for bacteriological analysis.

\subsection{Media and Reagents}

The media used for bacteriological analysis were MacConkey agar, Eosin-Methylene-Blue (EMB) agar, Salmonella-Shigella (SS) agar, Thiosulfate Citrate Bile Salts Sucrose (TCBS) agar, Muller Hinton agar, Nutrient broth (NB) and Peptone broth. The reagents used during the study were Lacto phenol-cotton-blue solution, Crystal violet, Gram's iodine, Safranin, 95\% Ethyl alcohol,3\% hydrogen peroxide, Kovac's \& indole reagent, Burritt's reagent A and B, normal physiological saline solution. Muller Hinton Agar plates, Phosphate buffered saline (PBS) solution, normal saline and distilled water, etc.

\subsection{Preparation of Sample}

Portions of Chotpoti samples were uniformly homogenized in mortar and pastel using sterile diluents as per recommendation of ISO. A quantity of $10 \mathrm{gm}$ homogenized sample of each Chotpoti was taken aseptically with a sterile spoon and transferred carefully into a sterile pestle containing $90 \mathrm{ml}$ of PBS. Later on 
using whirly mixture machine different serial dilutions ranging from 10-2 to 10-4 were prepared according to the standard method.

\subsection{Isolation and Identification of Bacteria from Chotpoti}

Homogenized samples were enriched into alkaline peptone water by overnight incubation at $37^{\circ} \mathrm{C}$. Overnight enriched culture was streaked and spreaded onto Salmonella-Shigella (SS) agar, Thiosulfate Citrate Bile Salts Sucrose (TCBS) agar and incubated at $37^{\circ} \mathrm{C}$ for $24 \mathrm{hrs}$. The cultural examination of Chotpoti samples for bacteriological analysis was done according to the standard method. Identification of bacteria was performed on the basis of colony morphology; Gram's staining reaction and biochemical test.

\subsection{Antibiotic Discs and Media Preparation}

Commercially available antibiotic disc has been used for the test to determine the drug sensitivity pattern. The commercially media were prepared according to the direction of the manufactures and the non-commercial media were prepared in the laboratory (Table 1).

\subsection{Enumeration of Total Viable Count (TVC)}

$0.1 \mathrm{ml}$ of each ten-fold dilution was transferred and spread on duplicate onto NA, EMB and MacConkey using a micropipette for each dilution for the determination of total bacterial count. The diluted samples were spread as quickly as possible on the surface of the plate with sterile glass spreader. The plates were kept in an incubator at $37^{\circ} \mathrm{C}$ for 24 hours. The results of the total bacterial count were expressed as the number of colony forming units (CFU) per gram of food samples.

\subsection{Colony Characteristics}

Colony characteristics such as shape, size, surface texture, edge and elevation, color and opacity developed on various selective media after $24 \mathrm{hrs}$ of incubation at $37^{\circ} \mathrm{C}$ were recorded.

\subsection{Gram's Staining}

Gram's staining of the pure culture was performed according to method described

Table 1. Antimicrobial agents with their disc concentration.

\begin{tabular}{cccc}
\hline SL. NO. & Antimicrobial agents & Symbol & Disc concentration $(\mu \mathrm{g} /$ disc $)$ \\
\hline 1 & Penicillin G & $\mathrm{P}$ & 10 \\
2 & Chloramphenicol & $\mathrm{CL}$ & 30 \\
3 & Streptomycin & $\mathrm{S}$ & 10 \\
4 & Tetracycline & $\mathrm{TE}$ & 30 \\
5 & Vancomycin & $\mathrm{VA}$ & 30 \\
\hline
\end{tabular}


by Aneja et al. (2003). Briefly, a single colony was picked up with a bacteriological loop, smeared on separate glass slide and fixed by gentle heating. Crystal violet was then applied on each smear to stain for two minutes and then washed with running tap water. Few drops of Gram's iodine were then added for few seconds. After washing with water, Safranin was added as counter stain and allowed to stain for 2 minutes. The slides were then washed with water, blotted and dried in air and then examined by a light microscope (100×).

\subsection{Biochemical Tests}

Biochemical tests were done in accordance to standard procedure [16]. Traditional media culturing and biochemical characterization of Enterobacteriaceae are still an authentic widely used methods for isolation and identification of bacteria from many sources including consumable foods [17].

\subsubsection{Catalase Test}

This test is used to different those bacteria that produce the enzyme catalase. To perform the test an amount of $2-3 \mathrm{ml}$ of $3 \%$ hydrogen peroxide solution was poured into a test tube. If the organisms are catalase producer, bubbles of oxygen are released.

\subsubsection{Sugar Fermentation Test}

The sugar fermentation test was performed by inoculating a loop full of NB culture of the organisms into each tube containing three basic sugars (e.g. Dextrose) separately and incubated for 24 hours at $37^{\circ} \mathrm{C}$. Acid production was indicated by the color change from reddish to yellow in the medium.

\subsubsection{Indole Test}

Five milliliter of peptone water was inoculated with the $5 \mathrm{ml}$ of bacterial culture and incubated at $37^{\circ} \mathrm{C}$ for 48 hours. Kovac's reagent $(0.5 \mathrm{ml})$ was added, shaked well and examined after 1 minute. A red color in the reagent layer indicates indole.

\subsubsection{Voges-Proskauer Test}

Five milliliter sterile glucose peptone water was inoculated with the $5 \mathrm{ml}$ of test organisms. It was incubated at $37^{\circ} \mathrm{C}$ for 48 hours.

\subsubsection{Triple Sugar Iron (TSI)}

This tube medium is used to identified Gram negative enteric bacteria based on few biochemical characteristics includes-glucose indicated by yellow butt, lactose fermentation-indicated by yellow slant and gas production indicated by presence of a crack or gas space, etc.

\subsubsection{Urease Broth}

This tube medium is used to identify Gram negative enteric based on the ability of the organism to produce the enzyme urease within 2 to 4 hours (rapid) or within 24 hours (late) of incubation. If the organism produces urease, this splits 
urea into ammonium, carbon-di-oxide and water.

\subsection{Antibiotic Sensitivity Test}

Antimicrobial drug susceptibility against two commonly used antibiotics was performed by disc diffusion method. The procedure of disc diffusion method is the isolated microbial colony was inoculating into Nutrient-Broth and incubated at $37^{\circ} \mathrm{C}$ for 24 hours. The plates were inverted and incubated at $37^{\circ} \mathrm{C}$ temperature for overnight. After incubation the diameter of the zone of complete inhibition (including diameter of the discs) was measured in millimeters with a ruler.

\section{Result and Discussion}

\subsection{Total Viable Count (TVC) of Chotpoti}

The TVC of Chotpoti samples collected from different vendors are presented in Table 2. Thirty-fold dilution was done to obtain single bacterial colony. In the current study, the highest TVC of Chotpoti was found in Nabinagar bus stand and the lowest TVC recorded in Pollybidut bus stand vendor $\left(3 \times 10^{5} \mathrm{CFU} / \mathrm{g}\right)$.

\subsection{Total Coliform Count (TCC) of Chotpoti}

The TCC of Chotpoti samples collected from different vendors are presented in Table 3. Twenty-fold dilution was done to obtain single bacterial colony. The highest TCC of Chotpoti was found in Nabinagar bus stand vendor $\left(3 \times 10^{6}\right.$ CFU/g) and the lowest TCC recorded at Pollybidut bus stand vendor (TNTC). The contamination might take place during processing, preparation and handling of the Chotpoti (Figure 1 \& Figure 2).

\subsection{Isolation and Identification of Bacteria from Chotpoti Sample}

The isolation of coliform bacteria from Chotpoti sample indicates fecal contamination. Presence of coliforms in the present study might be due to poor quality

Table 2. Total viable count of Chotpoti sold by vendors at Savar area.

\begin{tabular}{ccccc}
\hline Sample No: & Vendor places & Media plate & TVC $($ CFU/g) & $\begin{array}{c}\text { Acceptable or not } \\
\text { Acceptable }\end{array}$ \\
\hline 1 & Pollybidut bus stand vendor & Nutrient Agar & $3 \times 10^{5}$ & Not acceptable \\
2 & GhorapirMazar stand & Nutrient Agar & TNTC & Not acceptable \\
3 & Nabinagar bus stand & Nutrient Agar & TNTC & Not acceptable \\
\hline
\end{tabular}

Table 3. Total coliform count of Chotpoti sold by vendors at Savar area.

\begin{tabular}{ccccc}
\hline $\begin{array}{c}\text { Sample } \\
\text { no: }\end{array}$ & Vendor places & Media plate & TVC (CFUlgm) & $\begin{array}{c}\text { Acceptable or not } \\
\text { acceptable }\end{array}$ \\
\hline 1 & Pollybidut bus stand vendor & EMB agar & TNTC & Not acceptable \\
2 & GhorapirMazar stand & EMB agar & $6 \times 10^{5}$ & Not acceptable \\
3 & Nabinagar bus stand & EMB agar & $3 \times 10^{6}$ & Not acceptable \\
\hline
\end{tabular}

$\mathrm{EMB}=$ Eosin Methylene Blue. 


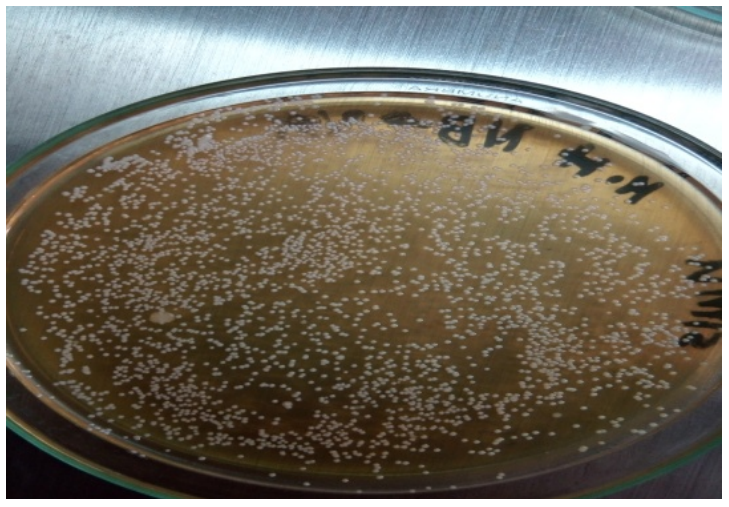

Figure 1. Total coliform count on EMB agar plate.

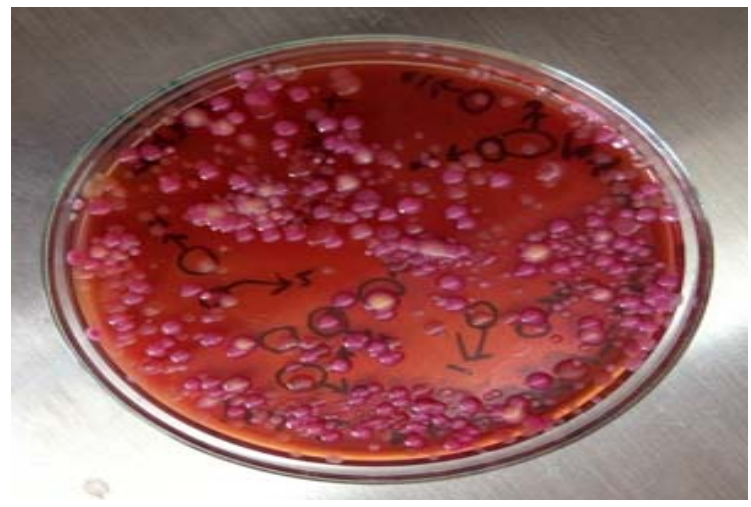

Figure 2. Bacterial colony on MacConkey agar plate.

of water used for washing of fruits, vegetables and utensils, inadequate storage of these at ambient temperatures in unhygienic places, maintenance of premises and personal hygienic of vendors. Microbiological studies carried out on street-food vending in several developing countries have reported high bacteria counts in food [18]. Identification of bacteria was performed by determining cultural characteristics, staining reactions and different biochemical properties. In the current study, four different genera of bacteria such as Escherichia coli, Klebsiella spp., Salmonella spp. and Shigella spp. were identified (Table 4).

\subsection{Cultural Characteristics}

The cultural characteristics of isolated bacteria exhibited on the selective media are presented in Table 5. Street foods are usually doing not receive any treatment as a result they are prone to get contaminated with food borne and antibiotic resistant bacteria that may cause public health hazard.

\subsection{Results of Antibiotic Sensitivity Tests}

A total of 08 isolates of 04 genera such as Escherichia coli, spp Klebsiella spp., Salmonella and Shigella spp. were subjected to antibiotic sensitivity assay. The results of antibiotic sensitivity assay are presented in Table 6 .

In this antibiogram sensitivity test some specific commonly used antibiotics 
Table 4. Summary of isolated bacteria from Chotpoti sold at different sources.

\begin{tabular}{ccc}
\hline Name of source & Bacterial type $(\boldsymbol{n})$ & Isolate number \\
\hline Pollybidut bus stand vendor & 02 & 1 (A, B) \\
Ghorapir Mazal stand vendor & 05 & $2(\mathrm{~A}, \mathrm{~B}, \mathrm{C}, \mathrm{D}, \mathrm{E})$ \\
Nabinagar bus stand vendor & 01 & $3(\mathrm{~A})$ \\
\hline
\end{tabular}

Table 5. Cultural characteristics of the bacterial isolates of Chotpoti.

\begin{tabular}{ccc}
\hline Serial No. & Name of selective media & Colony characteristics \\
\hline $\mathbf{1}$ & MacConkey agar & Pink colony \\
$\mathbf{2}$ & EMB agar & Metallic sheen colony \\
$\mathbf{3}$ & EMB agar & Brown mucoid colony \\
4 & TCBS agar & Not grow \\
\hline
\end{tabular}

Table 6. Resistant and sensitive patterns of the isolates of Chotpoti samples.

\begin{tabular}{cccccc}
\hline \multirow{2}{*}{ Isolate NO. } & \multicolumn{5}{c}{ Name of antibiotic disc } \\
\cline { 2 - 6 } & $\mathrm{P}$ & $\mathrm{S}$ & $\mathrm{TE}$ & $\mathrm{C}$ & $\mathrm{V}$ \\
\hline $1(\mathrm{~A})$ & $\mathrm{R}$ & $22 \mathrm{~mm}$ & $\mathrm{R}$ & $20 \mathrm{~mm}$ & $\mathrm{R}$ \\
$1(\mathrm{~B})$ & $\mathrm{R}$ & $20 \mathrm{~mm}$ & $17 \mathrm{~mm}$ & $26 \mathrm{~mm}$ & $\mathrm{R}$ \\
$2(\mathrm{~A})$ & $\mathrm{R}$ & $20 \mathrm{~mm}$ & $17 \mathrm{~mm}$ & $25 \mathrm{~mm}$ & $\mathrm{R}$ \\
$2(\mathrm{~B})$ & $\mathrm{R}$ & $22 \mathrm{~mm}$ & $\mathrm{R}$ & $29 \mathrm{~mm}$ & $\mathrm{R}$ \\
$2(\mathrm{C})$ & $\mathrm{R}$ & $21 \mathrm{~mm}$ & $15 \mathrm{~mm}$ & $15 \mathrm{~mm}$ & $\mathrm{R}$ \\
$2(\mathrm{D})$ & $\mathrm{R}$ & $20 \mathrm{~mm}$ & $17 \mathrm{~mm}$ & $26 \mathrm{~mm}$ & $\mathrm{R}$ \\
2 (E) & $\mathrm{R}$ & $22 \mathrm{~mm}$ & $\mathrm{R}$ & $15 \mathrm{~mm}$ & $18 \mathrm{~mm}$ \\
$3(\mathrm{~A})$ & $\mathrm{R}$ & $22 \mathrm{~mm}$ & $\mathrm{R}$ & $20 \mathrm{~mm}$ & $\mathrm{R}$ \\
\hline
\end{tabular}

Interpretation: $\mathrm{R}=$ resistant, $\mathrm{S}=$ sensitive.

are used against the specific microorganism. In this study, gram negative bacteria were found multidrug resistant. Antibiotic against which bacterial isolates of Chotpoti were found resistant were Penicillin G, Tetracycline and Vancomycin.

\subsection{Gram's Staining Results}

In this study, microbiological methods were used to identify bacteria isolated from Chotpoti samples. The results of cultural characteristics, Gram's staining, used to identify Escherichia coli, Klebsiella spp., Salmonella spp. and Shigella spp. were identified.

\subsection{Biochemical Test Results}

The biochemical identification of E. coli, Klebsiella spp. and Salmonella spp. were done by performing the biochemical test. The biochemical test was done as started on Bargen's manual of Determination Bacteriology. In many other studies, E. coli was detected frequently in street food samples [19]. In this project 14 
biochemical test has been done. Based on the result the major gram negative pathogenic bacteria have been identified. A total 08 gram negative bacterium was isolated from Chotpoti samples (Table 7).

\section{Conclusion}

Street foods are very much popular in the recent days. Improper personal hygiene can facilitate the transmission of the pathogenic bacteria found in environment and on people's hands via food to humans. Street foods have unique flavor, are easily accessible and cheap [20]. Hygiene in handling and cooking of street foods is very essential and personal hygiene is also very much important for food safety because human are the largest source of contamination. From this study, it clear that all the samples are microbiologically unacceptable to eat. A study on various types of ready-to-eat-food samples in Alice, South Africa showed bacterial growth in all the food types tested and found $22 \%$ of samples contaminated with Listeria spp. 18\% with Enterobacter spp. 12\% with Aeromonas hydrophila, $8 \%$ with Klebsiella oxytoca, $6.3 \%$ with Proteus mirabilis, $3.2 \%$ with Staphylococcus aureus and 2.4\% with Pseudomonas luteola [21]. Strict public health regulations should be established to control the situation. The maintenance of these street vended foods should be monitored cautiously. Insects and rodents carry pathogens from garbage, wastewater, and overloaded drain during

Table 7. Different biochemical test results with their respective microorganisms.

\begin{tabular}{|c|c|c|c|c|c|c|c|c|c|c|c|c|c|c|c|}
\hline \multirow{2}{*}{\begin{tabular}{l}
$\sum^{\circ}$ \\
\multirow{2}{*}{} \\
\multirow{2}{*}{} \\
\multirow{2}{*}{}
\end{tabular}} & \multirow{2}{*}{ 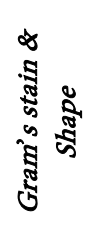 } & \multicolumn{3}{|c|}{$\begin{array}{l}\text { Carbohydrate } \\
\text { Fermentation }\end{array}$} & \multirow{2}{*}{ 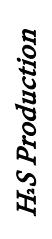 } & \multirow{2}{*}{ 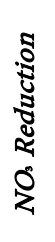 } & \multirow{2}{*}{ 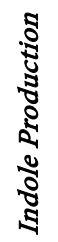 } & \multirow{2}{*}{ 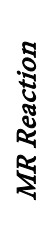 } & \multirow{2}{*}{ 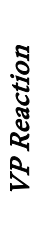 } & \multirow{2}{*}{ 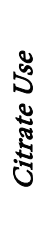 } & \multirow{2}{*}{ 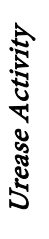 } & \multirow{2}{*}{ 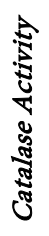 } & \multirow{2}{*}{ 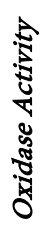 } & \multirow{2}{*}{ 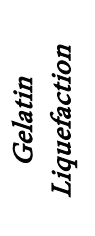 } & \multirow{2}{*}{ 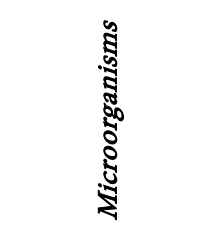 } \\
\hline & & 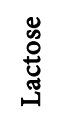 & 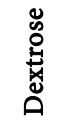 & 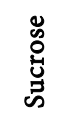 & & & & & & & & & & & \\
\hline $1(\mathrm{~A})$ & $\begin{array}{c}\text { Rod } \\
-\end{array}$ & AG & AG & - & - & + & + & + & - & - & - & + & - & - & Escherichia coli \\
\hline $1(\mathrm{~B})$ & $\begin{array}{c}\text { Rod } \\
-\end{array}$ & AG & AG & AG & - & + & - & + & + & + & + & + & - & - & Klebsiella spp. \\
\hline $2(\mathrm{~A})$ & $\begin{array}{c}\text { Rod } \\
-\end{array}$ & - & AG & A & + & + & - & + & - & + & - & + & - & - & Salmonella spp. \\
\hline $2(\mathrm{~B})$ & $\begin{array}{c}\text { Rod } \\
-\end{array}$ & AG & AG & A & - & + & + & + & - & - & - & + & - & - & Escherichia coli \\
\hline $2(\mathrm{C})$ & $\begin{array}{c}\text { Rod } \\
-\end{array}$ & AG & AG & AG & - & + & - & + & + & + & + & + & - & - & Klebsiella spp. \\
\hline 2 (D) & $\begin{array}{c}\text { Rod } \\
-\end{array}$ & AG & AG & AG & - & + & - & + & + & + & + & + & - & - & Klebsiella spp. \\
\hline $2(\mathrm{E})$ & $\begin{array}{c}\text { Rod } \\
-\end{array}$ & - & $\mathrm{A}$ & A & - & + & - & + & - & - & - & + & - & - & Shigella spp. \\
\hline $3(\mathrm{~A})$ & $\begin{array}{c}\text { Rod } \\
-\end{array}$ & - & AG & A & + & + & - & + & - & + & - & + & - & - & Salmonella spp. \\
\hline
\end{tabular}

MR: Methyl red; VP: Voges-Proskauer; AG: Acid and gas; A: Acid; $(+)=$ positive; $(-)=$ negative. Comments: Isolate number: 1 (A), 2 (B) = Escherichia coli; Isolate number: 1 (B), 2 (C), 2 (D) = Klebsiella spp.; Isolate number: 2 (A), 3 (A) = Salmonella spp.; Isolate number: 2 (E) = Shigella spp. 
their nutrient intake [22]. The government should take necessary steps to provide regular training and to create consciousness on food management and individual hygiene among street food vendors as well as consumers. Data of this study suggest that Chotpoti sold by street vendor contaminated with multidrug resistant food borne bacteria might pose public health hazard. For continuation of the present study the following research theme may be advocated to be conducted in future; pathogenic characterization of bacteria and molecular characterization of isolates by PCR analysis.

\section{Conflicts of Interest}

The authors declared no potential conflicts of the interest with respect to the research, authorship and/or publication of this article.

\section{References}

[1] Simopoulos, A.P. (2011) Evolutionary Aspects of Diet: The Omega-6/Omega-3 Ratio and the Brain. Molecular Neurobiology, 44, 203-215. https://doi.org/10.1007/s12035-010-8162-0

[2] Ghosh, M., Wahi, S., Kumar, M. and Ganguli, A. (2007) Prevalence of Enterotoxigenic Staphylococcus aureus and Shigella spp. in Some Raw Street Vended Indian Foods. International Journal of Environmental Health Research, 17, 151-156. https://doi.org/10.1080/09603120701219204

[3] Al Mamun, M., Rahman, S.M.M. and Turin, T.C. (2013) Knowledge and Awareness of Children's Food Safety among School-Based Street Food Vendors in Dhaka, Bangladesh. Foodborne Pathogens and Disease, 10, 323-330. https://doi.org/10.1089/fpd.2012.1283

[4] Kaufman, C.E., Rumbaugh Whitesell, N., Keane, E., Giago, C. and Sam, A. (2014) Effectiveness of Circle of Life, an HIV-Preventive Intervention for American Indian Middle School Youths: A Group Randomized Trial in a Northern Plains Tribe. American Journal of Public Healthh, 104, 106-112. https://doi.org/10.2105/AJPH.2013.301822

[5] Civitello, D.J., Forys, P., Johnson, A.P. and Hall, S.R. (2012) Chronic Contamination Decreases Disease Spread: A Daphnia-Fungus-Copper Case Study. Proceedings of the Royal Society B-Biological Sciences, 279, 3146-3153. https://doi.org/10.1098/rspb.2012.0684

[6] Higman, V.A., Varga, K., Aslimovska, L., Judge, P.J., Sperling, L.J., Rienstra, C.M. and Watts, A. (2011) The Conformation of Bacteriorhodopsin Loops in Purple Membranes Resolved by Solid-State MAS NMR Spectroscopy. Angewandte Chemie International Edition, 50, 8432-8435. https://doi.org/10.1002/anie.201100730

[7] Paterson, D.L. (2006) Resistance in Gram-Negative Bacteria: Enterobacteriaceae. American Journal of Infection Control, 34, 20-28. https://doi.org/10.1016/j.ajic.2006.05.238

[8] Fernandez-Fuentes, M.A., Elena, O.M., Hikmate, A., Ruben, P.P. and Antonio, G. (2014) Antimicrobial Resistance Determinants in Antibiotic and Biocideresistant Gram-Negative Bacteria from Organic Foods. Food Control, 37, 9-14. https://doi.org/10.1016/j.foodcont.2013.08.041

[9] Viswanathan, P. and Kaur, R. (2001) Prevalence and Growth of Pathogens on Salad Vegetables, Fruits and Sprouts. International Journal of Hygiene and Environmen- 
tal Health, 20, 205-213. https://doi.org/10.1078/S1438-4639(04)70030-9

[10] Mondol, G.C., Alam, M.G., Ahmad, T., Sharif, I.H., Hossain, M.A. and Uddin, M.E. (2018) Prevalence of Antibiotic Resistant Staphylococcus aureus among Patients Who Come to Seek Treatment in a Hospital of Bangladesh. Clinical Biotechnology and Microbiology, 2, 451-455.

[11] Rahman, M.M., Rahman, M.H. and Ansary, N.P. (2014) Safety Issues of Street Foods in Bangladesh. Journal of Biological Sciences and Technology, 2, 21-32.

[12] Biswas, S., Parvez, M.A.K., Shafiquzzaman, M. and Rahman, M.N. (2010) Isolation and Characterization of $E$. coli in Ready-to-Eat Foods Vended in Islamic University, Kushtia. Journal of Bio-Science, 18, 99-103.

[13] Zaid, K., Jamal, H. and Razak, C.K.L. (2011) The Prevalence of Microbiological Contamination in Ready-to-Eat Food and Factors Affecting It in Melaka. Journal of Community Health, 17, 64-73.

[14] Medina, E., Romero, C., Brenes, M. and De Castro, A. (2007) Antimicrobial Activity of Olive Oil, Vinegar and Various Beverages against Foodborne Pathogens. Journal of Food Protection, 70, 1194-1199. https://doi.org/10.4315/0362-028X-70.5.1194

[15] Estrada-Garcia, T., Lopez-Sancedo, C., Zamarripa-Ayala, B., Thompson, M.R., Gutierrez-Cogco, L., Mancera-Martinez, A. and Escobar-Gutierrez, A. (2004) Prevalence of E. coli and Salmonella spp in Street-Vended Food of Open Markets (Tianguis) and General Hygienic and Trading Practices in Mexico City. Epidemiology \& Infection, 132, 1181-1184. https://doi.org/10.1017/S0950268804003036

[16] Aneja, K.R. (2003) Staining and Biochemical Techniques. In: Experiments in Microbiology, Plant Pathology and Biotechnology, 4th Edition, New Age International Ltd., New Delhi.

[17] Worcman-Barninka, D., Destro, M.T., Fernandes, S.A. and Landgraf, M. (2001) Evaluation of Motility Enrichment on Modified Semi-Solid Rappaport-Vassiliadis Medium (MSRV) for the Detection of Salmonella in Foods. International Journal of Food Microbiology, 64, 387-393. https://doi.org/10.1016/S0168-1605(00)00484-0

[18] Das, A., Nagananda, G.S., Bhattacharya, S. and Bhardwaj, S. (2010) Microbiological Quality of Street-Vended Indian Chaats Sold in Bangalore. Journal of Biological Sciences, 10, 255-260. https://doi.org/10.3923/jbs.2010.255.260

[19] Lewis, J.E., Thompson, P., Rao, B. and Rajanna, B. (2006) Human Bacteria in Street Vended Fruit Juices: A Case Study of Visakhapatnam City, India. Internet Journal of Food Safety, 8, 35-38.

[20] Jouve, J.L., Aagaard-Hansen, J. and Aidara-Kane, A. (2010) Food Safety: Equity and Social Determinants. Equity, Social Determinants and Public Health Programmes, 8, 95.

[21] Nyenje, M.E., Odjadjare, C.E., Tanih, N.F., Green, E. and Ndip, R.N. (2012) Foodborne Pathogens Recovered from Ready-to-Eat Foods from Roadside Cafeterias and Retail Outlets in Alice, Eastern Cape Province, South Africa. International Journal of Environmental Research and Public Health, 9, 2608-2619. https://doi.org/10.3390/ijerph9082608

[22] Tambekar, D.H., Jaiswal, V.J., Dhanorkar, D.V., Gulhane, P.B. and Dudhane, M.N. (2008) Identification of Microbiological Hazards and Safety of Ready-to-Eat Food Vended in Streets of Amravati City, India. Journal of Applied Biosciences, 7, 195-201. 